\title{
Ny behandling reduserer selvskading hos ungdom
}

\author{
Av Iulie Nybakk Kvaal/UiO
}

\section{Ungdom som skader seg selv med vilje oppgir ofte at de også har forsøkt å ta sitt eget liv. Behandling som er direkte rettet mot å redusere selvskading og suicidalitet gir gode resultater.}

\begin{abstract}
RUNDT TI PROSENT av ungdommer som går i 9. og 10. trinn, og første klasse på videregående skole har rapportert at de én eller annen gang har forsøkt selvskading. Det er 2 ungdommer i hver skoleklasse som med vilje har prøvd å skade seg selv.

- Selvskading er ofte et av mange symptomer på at ungdommene har psykiske plager og vanskelige livshendelser, sier Anita Johanna Tørmoen. Hun har skrevet en doktorgradsavhandling på temaet ved Nasjonalt senter for selvmordsforskning og -forebygging (NSSF) ved Universitetet i Oslo.

Selvskading og selvmordsfors $ø$ k henger ofte sammen, slik at mange unge som selvskader også har forsøkt å ta sitt eget liv. Dette er ungdom med mange psykososiale belastninger,
\end{abstract} og er en vanskelig pasient-

\section{Behandlingen innebærer} både individuell terapi for ungdommene og ferdighetsopplæring sammen med familien hver uke gruppe å behandle.

Tormoens avhandling viser at Dialektisk atferdsterapi for ungdom (DBT-

A) kan være en lovende og effektiv behandling for unge med selvskadingsadferd. Ungdommene rapporterte mindre selvskading og reduksjon av selvmordstanker, og færre depressive symptomer etter behandling. Studien er den første i sitt slag i verden.

\footnotetext{
Selvskading er et symptom på emosjonelle vansker

Med selvskadingsatferd mener vi både selvmordsforsøk og ikke-suicidal selvskading. Å kutte seg er den mest vanlige måten å selvskade blant unge mennesker.
}

- De vanligste motivene for å drive med selvskading er et onske om befrielse fra intense og ubehagelige følelser, og noen har også et ønske om å dø. Det betyr at personer som rapporterer om selvskadingsatferd også kan være i risiko for å ta sitt eget liv, forteller Tormoen.

Selvskadingsatferd topper seg i ungdomstiden, og er mest utbredt blant jenter og ungdom med depresion, spiseproblemer, rusmisbruk eller atferdsvansker.

Mange av ungdommene oppgir også at de sliter med dårlig fysisk helse og lavt selvbilde.

\section{Fokus på mestring og kontroll $\mathbf{i}$ behandlingen} Det kan være utfordrende å hielpe ungdommer med gientatt selvskadingsatferd. Det er også vanskelig å være nær noen som selvskader.

- Selvskadingsatferd har en enorm innvirkning på pårørende, som kan kjenne på hjelpeløshet, skyldfølelse, tristhet og sinne, forteller Tørmoen.

En viktig del av behandlingen for unge som selvskader, er derfor å inkludere familiene deres slik at de sammen lærer mestringsteknikker og utvikler kontroll over egen suicidal atferd.

- DBT for ungdom er en 16-2o ukers intensiv behandling for ungdom som selvskader og deres familier, forteller Tørmoen.

Behandlingen innebærer både individuell terapi for ungdommene og ferdighetsopplæring sammen med familien hver uke. Sammen med terapeutene setter ungdommene seg noen tydelige mål de onsker å oppnå med behandlingen. Så jobber de aktivt med motivasjon for å nå disse målene.

- Parallelt med terapien lærer både ungdommene og foreldrene nye mestringsteknikker, og det undervises i temaer som mellom- 
